\title{
NITROGEN FIXATION IN STREAMS IN JACSKON HOLE, WY
}

\author{
LisA A. KunZA $\downarrow$ Robert O. HALl JR. \ Leslie Henry \\ UNIVERSITY OF WYOMING $\downarrow$ LARAMIE
}

Nitrogen fixation, the conversion of unreactive $\mathrm{N}_{2}$ gas from the atmosphere into a biologically usable form $\mathrm{NH}_{3}$, is the least studied process of the $\mathrm{N}$ cycle in stream ecology (Grimm and Petrone 1997). Tapping into the atmospheric $\mathrm{N}$ pool can only be accomplished naturally by $\mathrm{N}$-fixers. These diazotrophic organisms can contribute significantly to the autochthonous inputs of nitrogen into streams (Grimm and Petrone 1997). Without further investigations into $\mathrm{N}$-fixation we would ignore a potentially major $\mathrm{N}$ flux and transformation. Not only do we need to quantify this process, but also examine what factors control $\mathrm{N}$-fixation in streams.

Nitrogen fixation has been measured in only a few streams (Horne 1975, Horne and Carmiggelt 1975, Naiman and Melillo 1984, Triska et al. 1984, Grimm and Petrone 1997, Henry and Fisher 2003, Marcarelli and Wurtsbaugh 2006), although there are some other ongoing studies (Marcarelli and Wurtsbaugh, Ulseth and Flecker, Gettel, unpublished data). A forested stream in Oregon had N-fixation, associated with woody debris and moss, which was estimated to be $5 \%$ of the total $\mathrm{N}$ input (Triska et al. 1984). A nitrogen budget was established for a subarctic stream in Quebec, Canada with influence from beaver and associated woody debris, $\mathrm{N}$-fixation was $<1 \%$ (Naiman and Melillo 1984). From the above forested stream experiments $\mathrm{N}$-fixation does not appear to be an important contributor to the $\mathrm{N}$ budget of streams. However, $\mathrm{N}$ fixation accounted for $85 \%$ of all inputs to the benthic community in Sycamore Creek, Arizona (Grimm and Petrone 1997). Dodds (1989) examined Nostoc parmelioides collected from McRae Creek, Oregon and Halite Creek, Montana and compared nitrogen fixation of spherical (no influence by midge larva) and earshaped (containing midge larva, Cricotopus nostocicola or C. fuscatus) morphologies finding increased nitrogen fixation in midge containing
Nostoc. Contributions of $\mathrm{N}$-fixation to the stream $\mathrm{N}$ budgets vary among stream types and species of $\mathrm{N}$ fixing organisms, but there is no theory explaining which streams.

Nitrogen $(\mathrm{N})$ fixation is among the least studied processes of the $\mathrm{N}$ cycle in streams, despite its potentially dominant role in $\mathrm{N}$-limited systems. Many streams in NW Wyoming are N limited (J.L. Tank and R.O. Hall, unpublished data). We hypothesize that $\mathrm{N}$-fixation contributes to the $\mathrm{N}$ budgets of some streams. Cyanobacteria control the extent to which $\mathrm{N}$ uptake or transport occurs and may be important suppliers of $\mathrm{N}$ to downstream areas within these watersheds.

We measured nitrogen fixation rates using the acetylene reduction method in nine streams in three different land-use types in Grand Teton National Park and Jackson, WY (Reference-relatively unimpacted streams, Urban-in urban areas, and Agricultural-streams located on a ranch) (Figure 1). Reference and urban streams were not different, but this may be highly skewed due to high $\mathrm{N}$-fixation occurring in the Golf course stream. The agricultural streams may not be low due to $\mathrm{N}$ concentrations, but rather the alteration of stream flow and fine sediments.

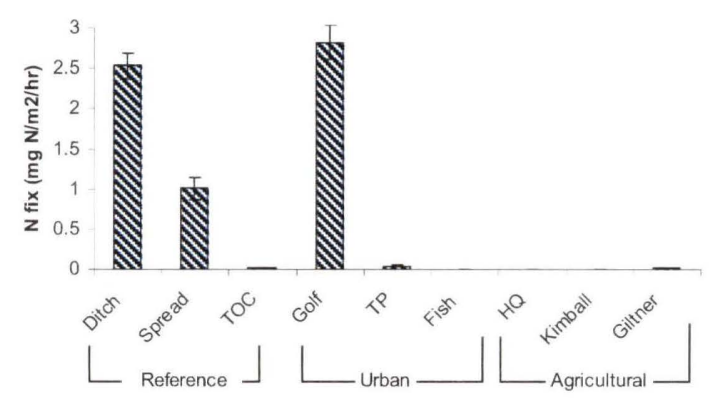


Figure 1. Mean stream nitrogen fixation rates $(n \geq 18)$. The results from summer 2005 nitrogen fixation measured using the acetylene reduction technique on 9 streams. Error bars represent standard error. $\mathrm{TOC}=$ Two Ocean Creek; $\mathrm{TP}=$ Teton Pines Waterway; $\mathrm{HQ}=$ Headquarters.

Intermittent flow patterns and fine sediments may not be suitable habitat for $\mathrm{N}$-fixing assemblages. The higher rates we measured are comparable to Sycamore Creek, Arizona (Grimm and Petrone 1997) and tropical systems(A.S. Flecker and A.J. Ulseth, unpublished) which are much higher than most lake, marine and estuarine systems (Howarth et al. 1988). Various ambient nitrate concentrations (Figure 2) are associated with the 9 streams (Figure 1). Ambient stream nitrate concentrations exceeding $10 \mu \mathrm{gN} / \mathrm{L}$ inhibit nitrogen fixation.

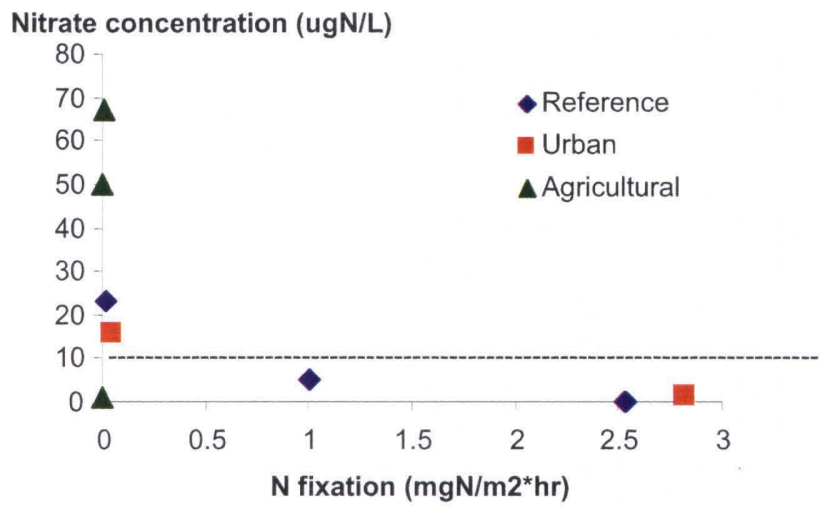

Figure 2. Ambient stream nitrate concentrations exceeding $10 \mu \mathrm{gN} / \mathrm{L}$ have low nitrogen fixation rates. The only exception from this study would be Headquarters which has $0.7 \mu \mathrm{gNO}_{3}-\mathrm{N} / \mathrm{L}$ and $0.002 \mathrm{mg} \mathrm{N} \mathrm{m}^{-2} \mathrm{~h}^{-1}$ nitrogen fixation rate. Headquarters has predominately silt substrate and intermittent flow.

Nitrogen can limit primary production even though there are organisms capable of fixing nitrogen (Vitousek and Howarth 1991). Nutrient limitation experiments have shown streams in many areas across multiple biomes to be $\mathrm{N}$ limited (Tank and Dodds 2003, Marcarelli and Wurtsbaugh 2006). Limiting nutrients on algal and phytoplankton community growth have been examined, but not specifically nitrogen fixing organisms. Examining effects of nutrient addition on $\mathrm{N}$-fixation rates will expand knowledge of how nutrient limitation relates to the $\mathrm{N}$-fixation process in streams.

To examine nutrient limitation on $\mathrm{N}$-fixing assemblages, nutrient releasing substrates were incubated in Two Ocean Lake Creek at five sites. Four treatments (control, N, P, N+P) were implemented according to Tank and Dodds (2003). Nitrogen fixation was significantly inhibited by the addition of nitrate (Figure 3). It appears as if phosphorus addition stimulates nitrogen fixation, but it is not statistically significant. This stream had low stream nitrogen fixation rates and results from streams with the highest nitrogen fixation rates may show larger increases in $\mathrm{N}$ - fixation due to phosphorus stimulation.

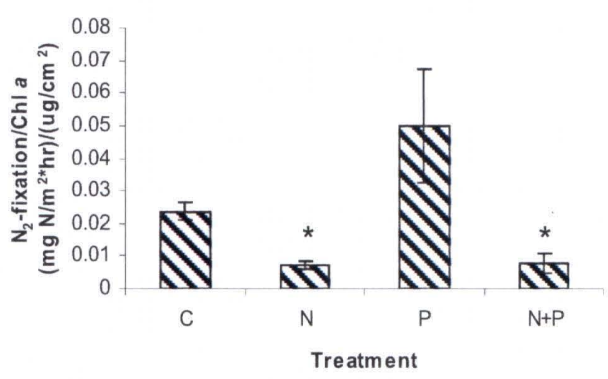

Figure 3. Mean treatment nitrogen fixation rates $(n=5)$. Error bars represent standard error. Addition of nitrogen inhibits $\mathrm{N}$-fixation, while addition of phosphorus may stimulate $\mathrm{N}$-fixation.

Nitrogen fixation is an understudied process in streams. Further research is needed to better understand the rates and controls of nitrogen fixation in Wyoming streams because the contribution of nitrogen fixation to stream nitrogen cycling can be large. We will continue to pursue these questions.

\section{$\downarrow$ Literature Cited}

Dodds, W.K. 1989. Photosynthesis of two morphologies of Nostoc parmelioides (cyanobacteria) as related to current velocities and diffusion patterns. Journal of Phycology 25:258-262.

Grimm, N.B., and K.C. Petrone. 1997. Nitrogen fixation in a desert stream ecosystem. Biogeochemistry 37:33-61.

Henry, J.C, and S.G. Fisher. 2003. Spatial segregation of periphyton communities in a desert stream: causes and consequences for $\mathrm{N}$ cycling. Journal of the North American Benthological Society 22: 511-527.

Horne, A.J. 1975. Algal nitrogen fixation in Californian streams: diel cycles and nocturnal fixation. Freshwater Biology 5:471-477. 
Horne, A.J. and C.J.W. Carmiggelt. 1975. Algal nitrogen fixation in Californian streams: seasonal cycles. Freshwater Biology 5:461470 .

Howarth, R.W., R.M. Marino, J. Lane, and J.J. Cole. 1988b. Nitrogen fixation in freshwater, estuarine, and marine ecosystems.1.Rates. and importance. Limnology and Oceanography 33:669-687.

Marcarelli, A.M. and W.A. Wurtsbaugh. 2006. Temperature and nutrient supply interact to control nitrogen fixation in oligotrophic streams: an experimental examination. Limnology and Oceanography 51:22782289.
Naiman, R.J. and J.M. Melillo. 1984. Nitrogen budget of a subarctic stream altered by beaver (Castor canadensis). Oecologia 62:150-155.

Tank, J.L. and W.K. Dodds. 2003. Nutrient limitation of epilithic and epixylic biofilms in ten North American streams. Freshwater Biology 48:1031-1049.

Triska, F. J., J.R. Sedell, K. Cromack, S.V. Gregory, and F.M. McCorison. 1984. Nitrogen budget for a small coniferous forest stream. Ecological Monographs 54:119-140.

Vitousek, P.M. and R.W. Howarth. 1991. Nitrogen limitation on land and in the sea: How can it occur? Biogeochemistry 13:87-115. 